\title{
Enhanced Removal of Golden XGL Dye by Clay Composites: Batch and Column Studies
}

\author{
Sana Nausheen ${ }^{1}$, Haq Nawaz Bhatti ${ }^{1 *}$, Muhammad Asif Hanif', \\ Khalil-ur-Rehman ${ }^{2}$ \\ ${ }^{1}$ Department of Chemistry, University of Agriculture, Faisalabad, Pakistan \\ ${ }^{2}$ Department of Biochemistry, University of Agriculture, Faisalabad, Pakistan
}

Received: 8 December 2016

Accepted: 16 January 2017

\begin{abstract}
The adsorption potential of native clay and clay composites was investigated for Golden XGL dye removal from aqueous solution in batch and fixed-bed column modes. Morphological structure and functional groups of the adsorbent were determined by Fourier transform infrared spectroscopy analysis. In batch adsorption studies maximum adsorption capacity was determined by optimization of operational parameters, i.e., $\mathrm{pH}$, adsorbent dose, contact time, initial dye concentration, and temperature. The effects of initial dye concentration, adsorbent bed height, and influent flow rate on fixed-bed column adsorption breakthrough curves were also evaluated. The obtained data was analyzed by the application of different equilibrium and kinetic models. Adsorption of Golden XGL dye onto native clay and clay composites was spontaneous, exothermic, and had great affinity between the adsorbate and adsorbent. The findings of this study revealed that clay composites are a potential adsorbent for cationic dye pollution remediation.
\end{abstract}

Keywords: Golden XGL, adsorbent, clay composite, adsorption, equilibrium isotherm

\section{Introduction}

It is well known that textile industries, pulp mills, and dyestuff manufacturing units discharge highly colored wastewaters that have provoked serious environmental concerns all over the world [1]. Various treatment processes such as ozonization, photochemical degradation, coagulation, ultrafiltration, oxidization, and adsorption have been widely investigated for the removal of dyes from wastewater. Due to the biological and chemical stability of dyestuff in a number of conventional water treatment methods, adsorption is considered an attractive and favorable alternative. For an efficient adsorption process,

*e-mail: hnbhatti2005@yahoo.com rapid removal and high adsorption capacity of adsorbent is required. The magnetic nanoparticles and their composites are extremely useful for the removal of dyes from wastewater streams [2]. Clays have often been used for the removal of organic pollutants and dyes [3] due to their high surface area and cation exchange capability. Clays can be modified to improve their sorption capability. One of these modification techniques is coating with magnetic particles [4]. Use of the magnetic particle in the nano scale has gained importance by many researchers. Recently, much attention has been paid to nanoparticle adsorbents, such as $\mathrm{MnO}_{2}, \mathrm{CeO}_{2}, \mathrm{Fe}_{3} \mathrm{O}_{4}, \mathrm{TiO}_{2}$, and $\mathrm{MnFe}_{2} \mathrm{O}_{4}$, etc., due to their basic properties, very small size, higher surface area-to-volume ratio, and unique morphology, which result in better kinetics for the adsorption of pollutants from aqueous solutions [5]. The extremely fine size of 
nanoparticles yields favorable characteristics. With a reduction in size, more atoms are located on the surface of a particle, which results in a notable increase in surface area of nanopowders. This imparts a significant change in surface energies and surface morphologies [6]. Magnetic separation is considered a fast and efficient technique for separating magnetic particles. Recently, considerable attention has been paid to the application of magnetic separation to solve environmental problems [7].

The aim of the present work is to prepare $\mathrm{MnFe}_{2} \mathrm{O}_{4}$ /clay nano composite and biocomposite of clay, which possess a high capacity for the removal of basic dye. Batch and column adsorption experiments are carried out and the adsorption mechanism are studied with the help of different models.

\section{Materials and Methods}

The native clay used in this research work was obtained from Khoshab, Pakistan, and was used without any treatment. Agro-wastes (cotton sticks, rice bran, sugarcane bagasse, corn cobs, sunflower, and peanut hulls) used in this research work were collected from different areas of Punjab, Pakistan. All the chemicals and reagents used in the present study were of analytical grade and mainly purchased from Sigma-Aldrich Chemical Co. (USA) and Merck (Germany).

\section{Preparation of Clay Composite Adsorbents}

Magnetic composites of clay were prepared by the co-precipitation method. $10 \mathrm{~g}$ of clay was added to a solution containing manganese (II) chloride and ferric chloride at room temperature. The $\mathrm{pH}$ was adjusted by adding boiling $\mathrm{NaOH}(5 \mathrm{~mol} / \mathrm{L})$ solution to around 10 and the solution was continuously stirred for $30 \mathrm{~min}$ and then stopped. After this, the suspension was heated to $95-100^{\circ} \mathrm{C}$ for $2 \mathrm{~h}$. The prepared magnetic composites were repeatedly washed with distilled water and dried in an oven at $105^{\circ} \mathrm{C}$ for $2 \mathrm{~h}$ [6]. Biocomposites were prepared by making slurry of clay with the biomasses. Firstly, screening was performed to find out the biomass with maximum adsorption capacity. Then biocomposite was prepared by mixing clay with the screened biomass. The biocomposite was prepared by making slurry of clay and biomass, allowed to cool and, finally ground, it and was used for further experiments.

\section{Batch Mode Study}

Batch adsorption experiments were carried out using an orbital shaker. The effects of adsorbent dose, contact time, solution $\mathrm{pH}$, initial dye concentration, and temperature on adsorption were investigated. For each experimental run, $0.05 \mathrm{~g}$ adsorbent and $50 \mathrm{~mL}$ of Golden $\mathrm{XG}$ dye solution of known concentration were transferred to a flask and agitated in a temperature-controlled shaker at a constant speed of $120 \mathrm{rpm}$ with a required adsorption time at ambient temperature and required $\mathrm{pH}$. At predetermined time intervals, the solutions were centrifuged at $5,000 \mathrm{rpm}$ for $10 \mathrm{~min}$. The effect of $\mathrm{pH}$ on adsorption of Golden XGL onto adsorbents was studied over a $\mathrm{pH}$ range of 2-11.The $\mathrm{pH}$ was adjusted by adding dilute aqueous solutions of $\mathrm{HCl}$ or $\mathrm{NaOH}$. The effect of adsorbent dose was determined in the range of 0.05-0.3 g. The adsorption kinetics was determined by analyzing adsorption capacity from the aqueous solution at different time intervals (10-120 min). For adsorption isotherms, Golden XGL dye solution of different concentrations in the range of 25-400 $\mathrm{mg} \mathrm{L}^{-1}$ was agitated until equilibrium was achieved. The effect of temperature on the adsorption characteristics was investigated by determining the adsorption isotherms at $302-337 \mathrm{~K}$. Concentration of dye was determined by finding out the absorbance characteristic wavelength using a UV-spectrophotometer (Schimadzu, Japan). A standard solution of the dye was taken and the absorbance was determined at different wavelengths to obtain a plot of absorbance versus wavelength. The wavelength corresponding to maximum absorbance $(\lambda \max )$ was determined from this plot. The $\lambda$ max for Golden XGL was found to be $438 \mathrm{~nm}$. Calibration curves were plotted between absorbance and concentration of the dye solution. The adsorbed amounts (q) of Golden XGL were calculated by the following equation:

$$
q_{e}=\frac{\left(c_{0}-c_{e}\right) V}{W}
$$

...where $\mathrm{C}_{\mathrm{o}}$ and $\mathrm{C}_{\mathrm{e}}$ are the initial and equilibrium concentrations of dye $\left(\mathrm{mg} \mathrm{L}^{-1}\right), \mathrm{W}$ is the mass of adsorbent $(\mathrm{g})$, and $\mathrm{V}$ is the volume of solution $(\mathrm{L})$.

Effects of presence of electrolytes, heavy metal ions, and surfactants were also determined.

\section{Fixed-Bed Adsorption Experiments}

The experiments were conducted in a $20 \mathrm{~mm}$ ID and $43 \mathrm{~cm}$ height glass column with an embedded stainless steel mesh for supporting the adsorbent layer. Fluidization and bypass flow of the system were retarded by introducing some glass wool on the mesh. The magnetic clay composite adsorbent corresponding to 1,2 , and $3 \mathrm{~cm}$ bed heights, respectively, were measured into the column. Influent flow rate of $1.8,2.7$, and $3.6 \mathrm{~mL} / \mathrm{min}$ in an upward direction with the aid of a peristaltic pump were used each for 50,75 , and $100 \mathrm{mg} / \mathrm{L}$ initial dye concentrations. The effluent Golden XGL dye concentration was measured at intervals at maximum wavelength (438 nm) using a UV-Vis spectrophotometer (Shimadzu UV/Vis Japan). The results of adsorption of basic dyes onto adsorbents in a continuous system were presented in the form of breakthrough curves that showed the loading behavior of dyes to be adsorbed from the solution expressed in terms of normalized concentration defined as the ratio of the outlet dye concentration to the inlet dye concentration as a function of time $\left(\mathrm{C}_{\mathrm{t}} / \mathrm{C}_{\mathrm{o}}\right.$ vs. $\left.\mathrm{t}\right)$. 
Breakthrough capacity $\mathrm{Q}_{0.5}$ (at $50 \%$ or $\mathrm{C}_{\mathrm{t}} / \mathrm{C}_{\mathrm{o}}=0.5$ ) expressed in $\mathrm{mg}$ of dye adsorbed per gram of adsorbent was calculated by the following equation:

\section{Breakthrough capacity $=$ \\ breakthrough time (at 50\%) $\mathrm{X}$ flow rate $\mathrm{X}$ initial dye conc. mass of the adsorbent in the bed}

\section{Adsorbent Characterization}

FTIR of native clay, $\mathrm{MnFe}_{2} \mathrm{O}_{4} /$ clay composite (composite that showed highest adsorption capacity), and dye-loaded composite were carried out to identify the chemical functional groups responsible for sorption. FTIR data were observed over $400-4,000 \mathrm{~cm}^{-1}$ by preparing $\mathrm{KBr}$ disks of sorbent material, and spectra were recorded using Bio-Rad Merlin software.

\section{Desorption Study}

Golden XGL dye from dye-loaded samples was desorbed by using $0.05 \mathrm{~N}$ of ETOH, $\mathrm{HCl}, \mathrm{H}_{2} \mathrm{SO}_{4}, \mathrm{H}_{3} \mathrm{PO}_{4}$, $\mathrm{NaCl}$, and $\mathrm{NaOH}$ as an eluent. Sorption procedure was studied by adding $0.1 \mathrm{~g}$ of selected adsorbent in $50 \mathrm{mg} / \mathrm{L}$ of dye solution at optimized $\mathrm{pH}$ and $30^{\circ} \mathrm{C}$ for three hours. The amount of dye sorbed $(\mathrm{mg} / \mathrm{g})$ was calculated, then filtered the dye solution and dried the dye-loaded adsorbent in an oven at $60^{\circ} \mathrm{C}$ and studied the desorption process by shaking the dried adsorbent with eluents. The amount of dye desorbed $(\mathrm{mg} / \mathrm{g})$ was again calculated. The percentage age desorption can be estimated by using the following equation:

$$
\begin{gathered}
\text { Desorption } \%=\text { Amount of dye desorbed } \\
(\mathrm{mg} / \mathrm{g}) / \text { Amount of dye sorbed }(\mathrm{mg} / \mathrm{g}) \times 100
\end{gathered}
$$

\section{Results and Discussion}

\section{Effect of $\mathrm{pH}$}

In the adsorption process, solution $\mathrm{pH}$ is one of the imperative parameters that affect the solubility of adsorbate, degree of ionization, and surface characteristics of the adsorbent [8]. The adsorption capacity of Golden $\mathrm{XGL}$ dye as a function of $\mathrm{pH}$ was determined by varying $\mathrm{pH}$ of the solutions over a range of 2.0-11 at the initial dye concentration of $50 \mathrm{mg} / \mathrm{L}$ and interaction time of $120 \mathrm{~min}$. The effect of $\mathrm{pH}$ on adsorption of Golden XGL dye is shown in Fig. 1. Golden XGL dye showed a maximum adsorption capacity at $\mathrm{pH} 9,6$, and 8 with native clay, $\mathrm{MnFe}_{2} \mathrm{O}_{4}$ /clay composite, and biocomposite, respectively. Maximum dye removal of Golden XGL i.e., $23.40 \mathrm{mg} / \mathrm{g}$, was obtained by using $\mathrm{MnFe}_{2} \mathrm{O}_{4} /$ clay. Results depicted that for native clay and biocomposite alkaline a range of $\mathrm{pH}$ was more favorable for the removal of Golden

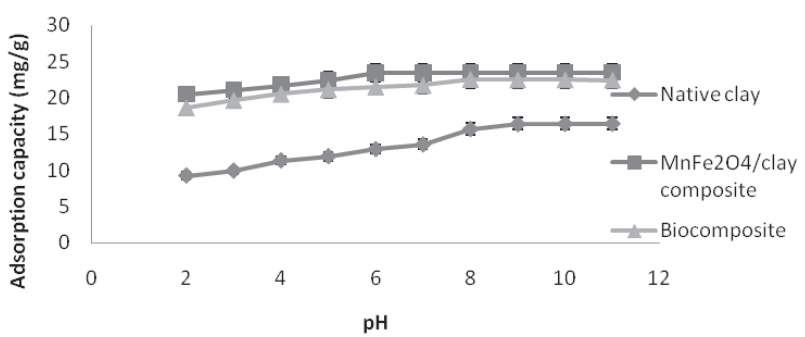

Fig. 1. Effect of pH on removal of Golden XGL dye.

XGL dye from aqueous media. Silanol groups on this surface become increasingly deprotonated as the $\mathrm{pH}$ of the adsorption system rises, thereby increasing the number of negatively charged adsorbent sites. Reduced adsorption of dye at acidic $\mathrm{pH}$ shows the presence of excess $\mathrm{H}+$ ions that compete with dye cations for the adsorption sites [9]. In an alkaline medium $(\mathrm{pH}>7)$, the surface of clay becomes negatively charged and electrostatic repulsion decreases with raising $\mathrm{pH}$ due to a reduction of positive charge density on the sorption edges, thus resulting in increased adsorption [10]. A similar theory was proposed by several earlier workers for metal adsorption on different adsorbents [11-12].

\section{Effect of Adsorbent Dose}

Adsorbent dose is a significant factor responsible for determining adsorption capacity. The results (Fig. 2) show that with enhancement in the adsorbent dose, adsorption capability of the adsorbent tends to decrease. Maximum adsorption capability ( $\mathrm{mg} / \mathrm{g}$ ) was obtained while using minimum adsorbent doses $(0.05 \mathrm{~g} / 50 \mathrm{~mL})$ with all types of adsorbents. When adsorbent dose was increased, adsorption capacity decreased from 30.64 to $5.64 \mathrm{mg} / \mathrm{g}$ (native clay), 42.18 to $8.30 \mathrm{mg} / \mathrm{g}$ $\left(\mathrm{MnFe}_{2} \mathrm{O}_{4}\right.$ /clay composite), and 40.59 to $7.60 \mathrm{mg} / \mathrm{g}$ (biocomposite) for Golden XGL. Noreen et al. (2013) [13] also determined the influence of biosorbent dose on removal of Drimarine Black CL-B via using lignocellulosic waste. They noticed that biosorption capability of the used adsorbents tends to decrease when adsorbent amount increases. They attributed this decrease in biosorption capacity to the aggregation of biosorbent particles by increasing biosorbent dose. Such aggregation results in reduction of the effective surface area of biosorbent for biosorption and causes enhancement in the diffusion

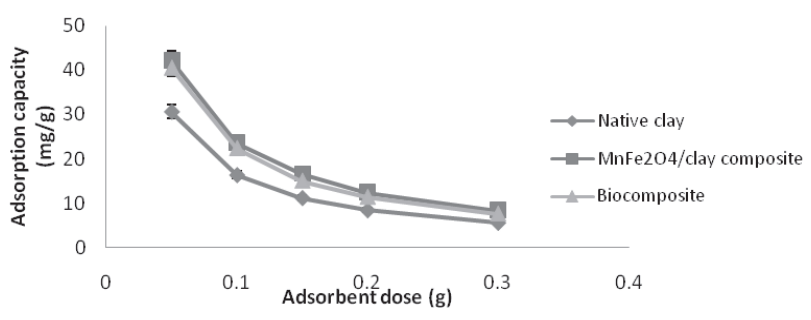

Fig. 2. Effect of adsorbent dose on removal of Golden XGL dye. 
path length. Asgher and Bhatti (2011) [14] studied the influence of biosorbent dose on adsorptive elimination of reactive blue 19 and 49 dyes by utilizing citrus waste. The amount of biosorbent was changed from 0.05 to $0.2 \mathrm{~g}$, and the biosorbent capacity was observed to be decreasing when biosorbent dose was enhanced.

\section{Effect of Contact Time at Various Initial Dye Concentrations and Kinetic Studies}

The effect of contact time on the adsorption process of Golden XGL dye onto adsorbents at three different initial concentrations of dye, i.e., 30,50 , and $70 \mathrm{mg} / \mathrm{L}$ at $30^{\circ} \mathrm{C}$ was studied with optimum adsorbent dose, and the results are illustrated in Figs 3-5. It was noticed that adsorption was rapid initially, then slowed, and finally reached equilibrium. In the case of 30 and $50 \mathrm{mg} / \mathrm{L}$ initial dye concentrations, the maximum uptake of dye was attained at $30 \mathrm{~min}$, while for $70 \mathrm{mg} / \mathrm{L}$ equilibrium occurred after $50 \mathrm{~min}$. Therefore, the contact time of $30-50 \mathrm{~min}$ was

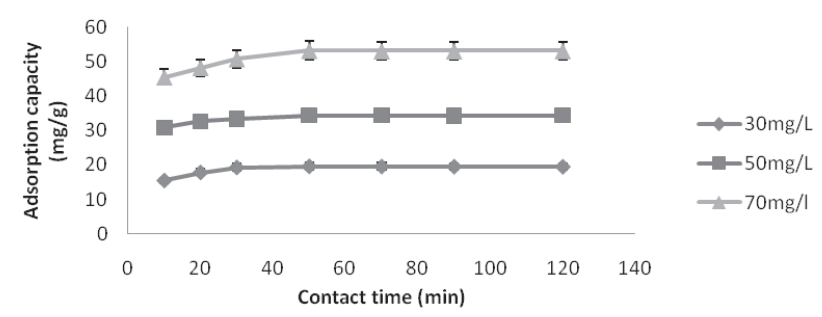

Fig. 3. Effect of contact time on removal of Golden XGL dye by native clay.

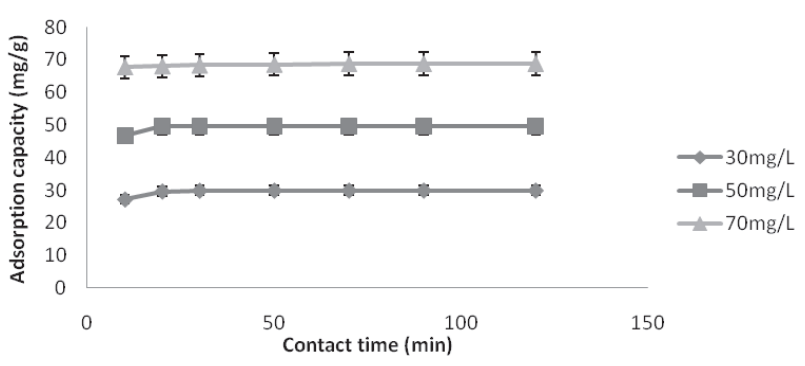

Fig. 4. Effect of contact time on removal of Golden XGL dye by $\mathrm{MnFe}_{2} \mathrm{O}_{4} /$ clay composite.

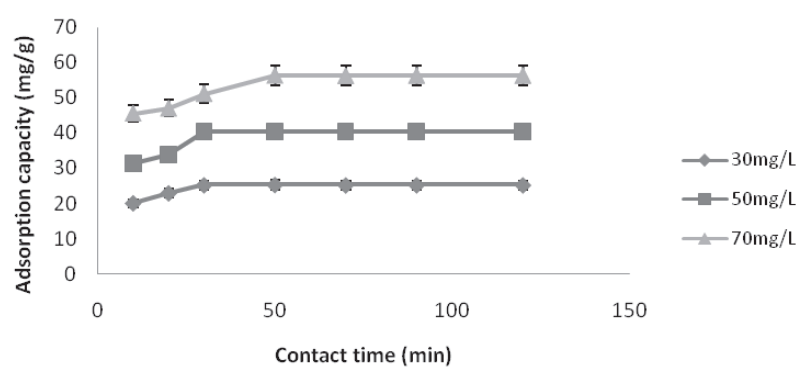

Fig. 5. Effect of contact time on removal of Golden XGL dye by biocomposite. sufficient to attain equilibrium for the adsorption process of studied dye, which was selected in the further experiments. When initial concentration of dye was $30 \mathrm{mg} / \mathrm{L}$, the amount of dye adsorbed at equilibrium was $20.50 \mathrm{mg} / \mathrm{g}$ (native clay), $28.05 \mathrm{mg} / \mathrm{g}\left(\mathrm{MnFe}_{2} \mathrm{O}_{4} /\right.$ clay composite), and $25.20 \mathrm{mg} / \mathrm{g}$ (biocomposite); while in the case of $50 \mathrm{mg} / \mathrm{L}$ initial dye concentration, the observed adsorption capacity was $31.49 \mathrm{mg} / \mathrm{g}$ (native clay), $44.94 \mathrm{mg} / \mathrm{g}\left(\mathrm{MnFe}_{2} \mathrm{O}_{4} /\right.$ clay composite), and $40.55 \mathrm{mg} / \mathrm{g}$ (biocomposite); while using $70 \mathrm{mg} / \mathrm{L}$ initial dye concentration the adsorption capacity was $47.90 \mathrm{mg} / \mathrm{g}$ (native clay), $59.60 \mathrm{mg} / \mathrm{g}\left(\mathrm{MnFe}_{2} \mathrm{O}_{4} /\right.$ clay composite), and $56.39 \mathrm{mg} / \mathrm{g}$ (biocomposite).

For the purpose of investigation of the rate-controlling step in the adsorption mechanism, the kinetic data were dealt with pseudo first-order, pseudo second-order, and intra particle diffusion kinetic models. The pseudo firstorder model is described in the following equation [4]:

$$
\log \left(q_{e}-q_{t}\right)=\log q_{e}-K_{1} \cdot \frac{1}{2.303}
$$

The pseudo second-order model is expressed in the following equation [5]:

$$
\frac{d q_{t}}{d_{t}}=K_{2}\left(q_{e}-q_{t}\right)^{2}
$$

... where $\mathrm{k}_{1}$ is the rate constant $(\mathrm{L} / \mathrm{min})$ while $\mathrm{k}_{2}(\mathrm{~g} / \mathrm{mg}$ min) is the rate constant of the pseudo second-order model, $\mathrm{q}_{\mathrm{e}}$ and $\mathrm{q}_{\mathrm{t}}$ are adsorption capabilities $(\mathrm{mg} / \mathrm{g})$ at equilibrium and time $\mathrm{t}$ (respectively), and $\mathrm{t}$ is the interaction time (min).

The kinetic parameters calculated from the pseudo first- and second-order and intra particle diffusion kinetic models are listed in Tables 1-3.

The results indicate that the pseudo second-order model fits the experiment data much better than the pseudo firstorder model, since all of its correlation coefficient $\left(\mathrm{R}^{2}\right)$ values are above 0.998 , which are higher than that of the pseudo first-order model (below 0.780). In addition, the theoretical calculated qe and cal values obtained from the pseudo second-order model are closer to the experimental ones (qe and exp) than that from the pseudo first-order equation. These results indicate that the rate-limiting step of the adsorption mechanism for Golden XGL dye was chemical adsorption. In order to investigate if film or pore diffusion was involved in the adsorption, the intra-particle diffusion model was further tested as follows [6]:

$$
q_{t}=K_{p i} t^{1 / 2}+C_{i}
$$

...where $\mathrm{K}_{\mathrm{pi}}\left(\mathrm{mg} / \mathrm{g} \min ^{1 / 2}\right)$ shows the rate constant of intraparticle diffusion and $\mathrm{C}_{\mathrm{i}}$ is the intercept that gives information about the boundary layer thickness. Lower values of co-relation co-efficient showed that the intraparticle diffusion model was not followed well by Golden XGL dye. As a summary of the kinetic studies, it was implied that chemical chelating reaction between 
Table 1. Kinetic modeling of data for the removal of Golden XGL dye by native clay.

\begin{tabular}{|c|c|c|c|c|c|c|c|c|c|c|c|}
\hline $\begin{array}{c}\mathrm{C}_{0} \\
(\mathrm{mg} / \mathrm{L})\end{array}$ & $\begin{array}{c}\text { Pseudo } \\
\text { first-order } \\
\mathrm{K}_{1} \\
(\mathrm{~L} / \mathrm{min})\end{array}$ & $\begin{array}{c}\mathrm{q}_{\mathrm{e}} \\
\text { experimen- } \\
\text { tal } \\
(\mathrm{mg} / \mathrm{g})\end{array}$ & $\begin{array}{c}\mathrm{q}_{\mathrm{e}} \\
\text { calculated } \\
(\mathrm{mg} / \mathrm{g})\end{array}$ & $\mathrm{R}^{2}$ & $\begin{array}{c}\text { Second- } \\
\text { order } \\
\mathrm{K}_{2} \\
(\mathrm{~g} / \mathrm{mg} \mathrm{min})\end{array}$ & $\begin{array}{c}\mathrm{q}_{\mathrm{e}} \\
\text { experimen- } \\
\text { tal } \\
(\mathrm{mg} / \mathrm{g})\end{array}$ & $\begin{array}{c}\mathrm{q}_{\mathrm{e}} \\
\text { calculated } \\
(\mathrm{mg} / \mathrm{g})\end{array}$ & $\mathrm{R}^{2}$ & $\begin{array}{c}\text { Intraparticle } \\
\text { diffusion } \\
\mathrm{K}_{\mathrm{pi}} \\
\left(\mathrm{mg} / \mathrm{g} \mathrm{min}^{1 / 2}\right)\end{array}$ & $\mathrm{C}_{\mathrm{i}}$ & $\mathrm{R}^{2}$ \\
\hline 30 & 0.0138 & 20.57 & 1.233 & 0.115 & 0.020 & 20.57 & 21.27 & 0.998 & 0.490 & 16.09 & 0.626 \\
\hline 50 & 0.029 & 31.49 & 5.4 & 0.695 & 0.008 & 31.49 & 33.33 & 0.998 & 1.080 & 21.75 & 0.600 \\
\hline 70 & 0.032 & 48 & 6.66 & 0.378 & 0.003 & 48 & 52.6 & 0.998 & 1.747 & 31.66 & 0.806 \\
\hline
\end{tabular}

Table 2. Kinetic modeling of data for the removal of Golden XGL dye by $\mathrm{MnFe}_{2} \mathrm{O}_{4} /$ clay composite.

\begin{tabular}{|c|c|c|c|c|c|c|c|c|c|c|c|}
\hline $\begin{array}{c}\mathrm{C}_{0} \\
(\mathrm{mg} / \mathrm{L})\end{array}$ & $\begin{array}{c}\text { Pseudo } \\
\text { first-order } \\
\mathrm{K}_{1} \\
\text { (L/min) }\end{array}$ & $\begin{array}{c}\mathrm{q}_{\mathrm{e}} \\
\text { experimen- } \\
\text { tal } \\
(\mathrm{mg} / \mathrm{g})\end{array}$ & $\begin{array}{c}\mathrm{q}_{\mathrm{e}} \\
\text { calculated } \\
(\mathrm{mg} / \mathrm{g})\end{array}$ & $\mathrm{R}^{2}$ & $\begin{array}{c}\text { Pseudo } \\
\text { second- } \\
\text { order } \\
\mathrm{K}_{2} \\
\text { (g/mg min) }\end{array}$ & $\begin{array}{c}\mathrm{q}_{\mathrm{e}} \\
\text { experimen } \\
\text {-tal } \\
(\mathrm{mg} / \mathrm{g})\end{array}$ & $\begin{array}{c}\mathrm{q}_{\mathrm{e}} \\
\text { calculated } \\
(\mathrm{mg} / \mathrm{g})\end{array}$ & $\mathrm{R}^{2}$ & $\begin{array}{c}\text { Intraparticle } \\
\text { diffusion } \\
\mathrm{K}_{\mathrm{pi}} \\
\left(\mathrm{mg} / \mathrm{g} \mathrm{min}{ }^{1 / 2}\right)\end{array}$ & $\mathrm{C}_{\mathrm{i}}$ & $\mathrm{R}^{2}$ \\
\hline 30 & 0.029 & 28.07 & 0.937 & 0.332 & 0.042 & 28.07 & 28.6 & 0.999 & 0.300 & 25.34 & 0.603 \\
\hline 50 & 0.043 & 44.94 & 3.341 & 0.583 & 0.014 & 44.94 & 47.61 & 0.999 & 0.766 & 37.99 & 0.603 \\
\hline 70 & 0.027 & 60.06 & 3.784 & 0.396 & 0.011 & 60.06 & 62.5 & 0.999 & 0.798 & 52.56 & 0.829 \\
\hline
\end{tabular}

Table 3. Kinetic modeling of data for the removal of Golden XGL dye by biocomposite.

\begin{tabular}{|c|c|c|c|c|c|c|c|c|c|c|c|}
\hline $\begin{array}{c}\mathrm{C}_{0} \\
(\mathrm{mg} / \mathrm{L})\end{array}$ & $\begin{array}{c}\text { Pseudo } \\
\text { first-order } \\
\mathrm{K}_{1} \\
\text { (L/min) }\end{array}$ & $\begin{array}{c}\mathrm{q}_{\mathrm{e}} \\
\text { experimen- } \\
\text { tal } \\
(\mathrm{mg} / \mathrm{g})\end{array}$ & $\begin{array}{c}\mathrm{q}_{\mathrm{e}} \\
\text { calculated } \\
(\mathrm{mg} / \mathrm{g})\end{array}$ & $\mathrm{R}^{2}$ & \begin{tabular}{|c} 
Pseudo \\
second- \\
order \\
$\mathrm{K}_{2}$ \\
(g/mg min)
\end{tabular} & $\begin{array}{c}\mathrm{q}_{\mathrm{e}} \\
\text { experimen } \\
\text {-tal } \\
(\mathrm{mg} / \mathrm{g})\end{array}$ & $\begin{array}{c}\mathrm{q}_{\mathrm{e}} \\
\text { calculated } \\
(\mathrm{mg} / \mathrm{g})\end{array}$ & $\mathrm{R}^{2}$ & 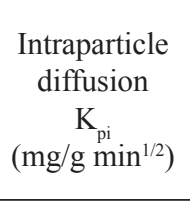 & $\mathrm{C}_{\mathrm{i}}$ & $\mathrm{R}^{2}$ \\
\hline 30 & 0.032 & 25.28 & 2.317 & 0.541 & 0.020 & 25.28 & 26.3 & 0.999 & 0.548 & 20.3 & 0.575 \\
\hline 50 & 0.050 & 40.55 & 6.053 & 0.735 & 0.009 & 40.55 & 41.66 & 0.999 & 1.087 & 30.66 & 0.617 \\
\hline 70 & 0.052 & 56 & 1.398 .9 & 0.780 & 0.004 & 56 & 58.8 & 0.999 & 1.549 & 41.87 & 0.808 \\
\hline
\end{tabular}

dye ions and active points of the adsorbents had effects on the adsorption processes [15]. Some previous kinetic studies showed similar results. Pan et al. (2012) [16] investigated the adsorption of $\mathrm{Hg}$ (II) onto the surface of mercapto-engineered magnetic $\mathrm{Fe}_{3} \mathrm{O}_{4}$ nano adsorbent, and the adsorption equilibrium was reached within $1 \mathrm{~h}$. Also, adsorption followed the pseudo second-order model. Sadaf et al. (2014) [17] investigated the effect of interaction time on adsorptive removal of Direct Violet 51 with sugarcane bagasse as adsorbent and observed that equilibrium was attained within 30 minutes.

\section{Effect of Initial Dye Concentration and Isothermal Studies}

At the initial stages of the adsorption process, the adsorption capacity was enhanced rapidly. The dye ions adsorbed on the surface of the adsorbent and after saturating the adsorbent surface, ions moved into porous sites. The initial concentration of dye plays a significant role to reduce the resistance of dye mass transfer among the solid and aqueous phases. Thus the adsorption capacity was enhanced by increasing the initial dye concentration [18]. The results are expressed in Fig. 6. This might be due to the increased number of interactions among the adsorbent and the ions of dye [19]. Similar results were observed while studying biosorption behavior of basic dye by using sesame hulls [20]. When initial concentration of dye was enhanced from $25-400 \mathrm{mg} / \mathrm{L}$, adsorption capacity was enhanced from 12.99-123.54 $\mathrm{mg} / \mathrm{g}$ (native clay), 23.59-169.5 mg/g ( $\mathrm{MnFe}_{2} \mathrm{O}_{4} /$ clay composite), and

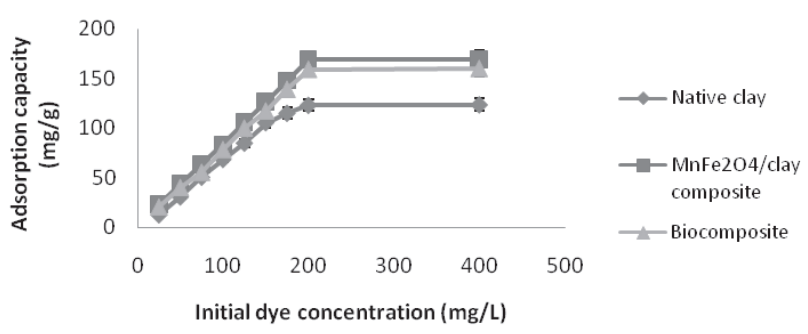

Fig. 6. Effect of initial dye concentration on removal of Golden XGL dye. 
20.59-160.5 mg/g (biocomposite) for Golden XGL dye. In order to investigate the interactive behavior between the adsorbent and adsorbate at different initial dye concentrations, five different isotherm models were employed to evaluate the experimental data. The Langmuir isotherm assumes that monolayer adsorption takes place on an adsorbent that has a structurally homogeneous surface, on which the binding sites have the same affinity for adsorption, and no interaction occurs between adsorbates [21]. The linear form of the Langmuir isotherm is given in the following equation:

$$
\frac{C_{e}}{q_{e}}=\frac{1}{q_{m} b}+\frac{C_{e}}{q_{m}}
$$

... where $\mathrm{q}_{\mathrm{m}}$ shows maximum adsorption capacity $(\mathrm{mg} / \mathrm{g}$ ) and $b$ is value for Langmuir constant associated to energy of adsorption (L/mg). Numerical values of the Langmuir constants and correlation co-efficient, i.e., $\mathrm{R}^{2}$ for the adsorption of Golden XGL dye, are mentioned in Table 4. $\mathrm{R}_{\mathrm{L}}$ is an imperative feature of the Langmuir adsorption isotherm model that could be calculated as shown in equation (8) [22]. Furthermore, the degree of suitability of adsorbent towards adsorbate could be estimated from the values of separation factor constant $\left(R_{L}\right)$, which has always been used to indicate whether adsorption is favorable or not. The value of RL will indicate that the type of isotherm is irreversible $(R L=0)$, favorable $(0<R L<1)$, linear $(\mathrm{RL}=1)$, or unfavorable $(\mathrm{RL}>1)$, which can be calculated from the following equation (8):

$$
R_{L}=\frac{1}{1+b C_{o}}
$$

...where $\mathrm{C}_{\mathrm{o}}$ denotes initial concentration of dye and $\mathrm{b}$ stands for Langmuir constant. The value of $R_{L}$ suggests that the adsorption process with all types of adsorbent is favorable. The well-known Freundlich isotherm predicts that adsorption occurs on an energetically heterogeneous surface, on which the adsorbed molecules are interactive and the amount of solute adsorbed raises infinitely with the increase of the concentration. Its linear equation is shown in the following equation (9):

$$
\log q_{e}=\log K_{F}+\frac{1}{n} \log C_{e}
$$

... where $\mathrm{K}_{\mathrm{F}}$ and $\mathrm{n}$ are the Freundlich constants related to adsorption capacity and intensity, respectively.

The Temkin isotherm model is based on the assumption that there is non-distinguishable spreading of binding energies over the number of exchanging sites onto adsorbent surface. The Temkin isotherm linear form may be expressed as (10):

$$
q_{e}=B \ln A+B \ln C_{e}
$$

\begin{tabular}{|c|c|c|c|}
\hline \multirow{2}{*}{$\begin{array}{l}\text { Isotherm } \\
\text { models }\end{array}$} & \multicolumn{3}{|c|}{ Golden XGL } \\
\hline & $\begin{array}{l}\text { Native } \\
\text { clay }\end{array}$ & $\begin{array}{c}\mathrm{MnFe}_{2} \mathrm{O}_{4} / \text { clay } \\
\text { composite }\end{array}$ & Biocomposite \\
\hline \multicolumn{4}{|c|}{ Langmuir } \\
\hline $\begin{array}{c}\mathrm{q}_{\mathrm{m}} \\
\text { Calculated } \\
(\mathrm{mg} / \mathrm{g})\end{array}$ & 167.7 & 173.02 & 167.03 \\
\hline $\begin{array}{c}\mathrm{q}_{\mathrm{m}} \\
\text { Experimental } \\
(\mathrm{mg} / \mathrm{g})\end{array}$ & 123.54 & 169.50 & 160.50 \\
\hline $\mathrm{b}$ & 0.018 & 0.078 & 0.037 \\
\hline $\mathrm{R}_{\mathrm{L}}$ & 0.526 & 0.204 & 0.350 \\
\hline $\mathrm{R}^{2}$ & 0.834 & 0.993 & 0.972 \\
\hline \multicolumn{4}{|c|}{ Freundlich } \\
\hline $\mathrm{K}_{\mathrm{F}}$ & 5.1 & 25.8 & 13.4 \\
\hline $\mathrm{n}$ & 1.46 & 2.3 & 1.8 \\
\hline $\mathrm{R}^{2}$ & 0.666 & 0.816 & 0.752 \\
\hline \multicolumn{4}{|c|}{ Temkin } \\
\hline A & 5.5 & 1.2 & 2.5 \\
\hline B & 39.77 & 34.43 & 41.31 \\
\hline $\mathrm{R}^{2}$ & 0.775 & 0.791 & 0.764 \\
\hline \multicolumn{4}{|c|}{ Harkins-Jura } \\
\hline A & 500 & - & 1000 \\
\hline B & 2.5 & - & 2 \\
\hline $\mathrm{R}^{2}$ & 0.354 & 0.622 & 0.521 \\
\hline \multicolumn{4}{|c|}{ Doubinin-Radushkevich } \\
\hline $\mathrm{q}_{\mathrm{m}}(\mathrm{mg} / \mathrm{g})$ & 111.9 & 109.1 & 108.6 \\
\hline$\beta\left(\mathrm{mol}^{2} \mathrm{~kJ}{ }^{-2}\right)$ & 0.00006 & 0.0000009 & 0.000007 \\
\hline $\mathrm{E}\left(\mathrm{kJmol}^{-1}\right)$ & 91.74 & 746.26 & 267.37 \\
\hline $\mathrm{R}^{2}$ & 0.943 & 0.629 & 0.712 \\
\hline
\end{tabular}

Table 4. Equilibrium modeling of data for the removal of Golden XGL dye.

...where $\mathrm{B}=\mathrm{RT} / \mathrm{b}, \mathrm{T}$ stands for absolute temperature in $\mathrm{K}$, $\mathrm{R}$ denotes universal gas constant $\left(8.314 \mathrm{~J} \mathrm{~mol}^{-1} \mathrm{~K}^{-1}\right)$, and $\mathrm{b}$ is Temkin constant. A expresses the equilibrium binding constant and $\mathrm{B}$ indicates sorption heat.

The Harkins-Jura isotherm is used to explain the multilayered adsorption phenomena. The linear form of the Harkins-Jura isotherm is shown in the following equation (11):

$$
\frac{1}{q e^{2}}=\left(\frac{B}{A}\right)-\left(\frac{1}{A}\right) \log C e
$$

The Doubinin-Radushkevich (D-R) isotherm assumes that the surface is not homogenous. It is used to express the porosity of apparent free energy. 


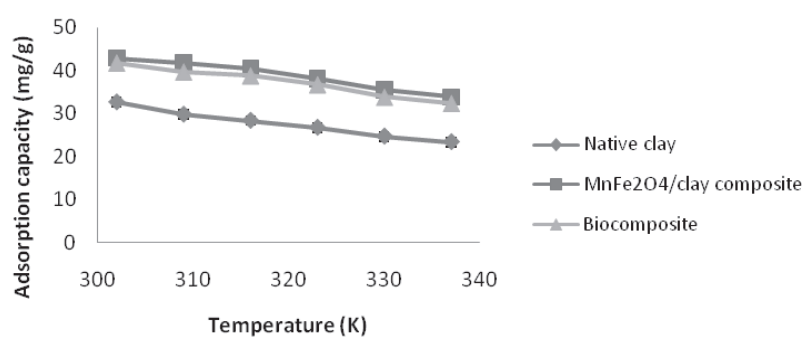

Fig. 7. Effect of temperature on removal of Golden XGL dye.

The (D-R) isotherm model's (Doubinin-Radushkevich, 1947) linear form is expressed as (12):

$$
\ln q_{e}=\ln q_{m}-\beta \varepsilon^{2}
$$

$\ldots$ where $\beta$ is the constant related to adsorption energy, $\mathrm{q}_{\mathrm{m}}$ is the theoretical saturation capacity, and $\varepsilon$ is the Polanyi potential.

\section{Effect of Temperature and Thermodynamic Studies}

The effect of temperature on adsorption kinetics was determined under isothermal conditions in temperatures ranging from 302-337 $\mathrm{K}$. The dependence of adsorption capacity on temperature is shown in Fig. 7. The results show that adsorption capacity of adsorbents tends to decrease with rising temperatures, which indicates that the adsorption process of Golden XGL dye was an exothermic phenomenon. Golden XGL dye showed the highest adsorption capacity at $302 \mathrm{~K}$. The reduction in adsorption capability of the dye at higher temperature might be attributed to the weakening of adsorptive forces that are mainly responsible for the adsorption of dye molecules onto the adsorbent surface [23]. The adsorptive removal of dye was observed to be decreased from 32.63 to $23.35 \mathrm{mg} / \mathrm{g}$ (native clay), 42.85 to $33.83 \mathrm{mg} / \mathrm{g}\left(\mathrm{MnFe}_{2} \mathrm{O}_{4} /\right.$ clay composite), and 41.69 to $32.41 \mathrm{mg} / \mathrm{g}$ (biocomposite) with a rise in temperature for Golden XGL dye. Kareem and Hussien (2012) [24] explored the effect of temperature on the exclusion of Rhodamine B, Congo Red, and Disperse Blue dyes from water media utilizing flint clay as an adsorbent. The results revealed that the percentage of adsorbed amounts of these dyes onto the adsorbent was decreased with temperature rise of the dye solution (from $20-40^{\circ} \mathrm{C}$ ). They observed that a reduction in the adsorption capability with a rise in temperature is indicative of the exothermic nature of the adsorption phenomenon.

Thermodynamic factors like entropy change $(\Delta S)$, enthalpy change $(\Delta \mathrm{H})$, and Gibbs free energy change $(\Delta \mathrm{G})$ were calculated from thermal data of Golden XGL dye and are expressed in Table 5. The equation is given as under (13):

$$
\ln \left(K_{d}\right)=\frac{\Delta \mathrm{S}^{\circ}}{R}-\frac{\Delta \mathrm{H}^{\circ}}{R} \times \frac{1}{T}
$$

... where $\mathrm{K}_{\mathrm{d}}=\mathrm{qe} / \mathrm{Ce} \mathrm{R}$ represents the gas constant and $\mathrm{T}$ shows absolute temperature. The adsorption process of Golden XGL dye onto native clay, $\mathrm{MnFe}_{2} \mathrm{O}_{4}$ /clay composite, and biocomposite is exothermic in nature.

\section{Effect of Electrolytes, Heavy Metal Ions, and Detergents on the Golden XGL Dye Adsorption Process}

The effect of the ionic strength on the adsorption phenomenon of Golden XGL dye was studied by adding different concentrations of electrolytes (ranging from 0.1 to $0.5 \mathrm{M}) \mathrm{AlCl}_{3} 6 \mathrm{H}_{2} \mathrm{O}, \mathrm{NaCl}, \mathrm{CaCl}_{2} 2 \mathrm{H}_{2} \mathrm{O}, \mathrm{MgSO}_{4} 7 \mathrm{H}_{2} \mathrm{O}$, and $\mathrm{KNO}_{3}$ in $50 \mathrm{mg} / \mathrm{L}$ each dye solution, containing $0.05 \mathrm{~g} / 50 \mathrm{~mL}$ of $\mathrm{MnFe}_{2} \mathrm{O}_{4} /$ clay composite adsorbent (adsorbent that showed highest adsorption capacity). The amount of dye adsorbed was observed to be decreased with increases in electrolyte concentration (Fig. 8). Various heavy metal ions $(\mathrm{Pb}, \mathrm{Cd}, \mathrm{Zn}, \mathrm{Co}$, and $\mathrm{Cu})$ were used in different concentrations, i.e., $50-250 \mathrm{mg} / \mathrm{L}$ to determine the effect of their existence on the adsorptive removal

\begin{tabular}{|c|c|c|c|c|c|c|c|c|c|}
\hline \multirow{3}{*}{$\begin{array}{c}\text { Temperature } \\
\text { (K) }\end{array}$} & \multicolumn{9}{|c|}{ Golden XGL } \\
\hline & \multicolumn{3}{|c|}{ Native clay } & \multicolumn{3}{|c|}{$\mathrm{MnFe}_{2} \mathrm{O}_{4} /$ clay composite } & \multicolumn{3}{|c|}{ Biocomposite } \\
\hline & $\begin{array}{c}\Delta \mathrm{G}^{\circ} \\
(\mathrm{kJ} / \mathrm{mol})\end{array}$ & $\begin{array}{c}\Delta \mathrm{H}^{\circ} \\
(\mathrm{kJ} / \mathrm{mol})\end{array}$ & $\begin{array}{c}\Delta \mathrm{S}^{\circ} \\
\left(\mathrm{Jmol}^{-1} \mathrm{~K}^{-1}\right)\end{array}$ & $\begin{array}{c}\Delta \mathrm{G}^{\circ} \\
(\mathrm{kJ} / \mathrm{mol})\end{array}$ & $\begin{array}{c}\Delta \mathrm{H}^{\circ} \\
(\mathrm{kJ} / \mathrm{mol})\end{array}$ & $\begin{array}{c}\Delta \mathrm{S}^{\circ} \\
\left(\mathrm{Jmol}^{-1} \mathrm{~K}^{-1}\right)\end{array}$ & $\begin{array}{c}\Delta \mathrm{G}^{\circ} \\
(\mathrm{kJ} / \mathrm{mol})\end{array}$ & $\begin{array}{c}\Delta \mathrm{H}^{\circ} \\
(\mathrm{kJ} / \mathrm{mol})\end{array}$ & $\begin{array}{c}\Delta \mathrm{S}^{\circ} \\
\left(\mathrm{Jmol}^{-1} \mathrm{~K}^{-1}\right)\end{array}$ \\
\hline 302 & -1.48 & -17.95 & -54.54 & -4.61 & -26.62 & -72.83 & -4.03 & -24.31 & -67.12 \\
\hline 309 & -1.10 & & & -4.10 & & & -3.56 & & \\
\hline 316 & -0.72 & & & -3.59 & & & -3.09 & & \\
\hline 323 & -0.34 & & & -3.08 & & & -2.62 & & \\
\hline 330 & -0.03 & & & -2.57 & & & -2.15 & & \\
\hline 337 & -0.42 & & & -2.06 & & & -1.68 & & \\
\hline
\end{tabular}

Table 5. Thermodynamic parameters for the removal of Golden XGL. 


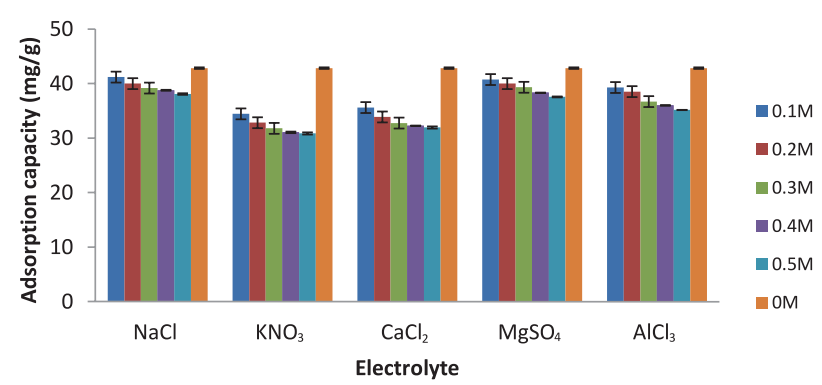

Fig. 8. Effect of the presence of electrolytes on adsorption potential of $\mathrm{MnFe}_{2} \mathrm{O}_{4} /$ clay composite for removal of Golden XGL dye.

of Golden XGL dye from their aqueous solutions, and results are represented in Fig. 9. The result revealed that the occurrence of heavy metal ions enhances adsorption of Golden XGL dye. Increasing concentrations of metal ions causes a further rise in dye removal. The enhancement in adsorption capacity with heavy metal ions may be due to the interaction among dye molecules and heavy metal ions that cause the aggregation or precipitation of dye molecules, thus reducing its solubility in solution, which results in enhancement of the dye adsorption on adsorbent [25]. The effect of surfactants (CTAB, SDS, Tween 80, Excel, and Ariel) was studied on the removal of Golden XGL dye from their solution. Their results, shown in Fig. 10, indicate that the adsorption capacity was markedly reduced in the presence of surfactants. Bhatti and Nausheen (2015) [26] also observed that the presence of surfactants in dye solution causes a remarkable reduction in adsorption capacity of agrowaste for removal of Terquoise Blue PG dye.

\section{Fixed Bed Adsorption Experiments}

Breakthrough curves for Goldeen XGL dye adsorption by $\mathrm{MnFe}_{2} \mathrm{O}_{4}$ /Clay composite were determined. Usually, the resulting breakthrough curves show a typical S-shaped profile; this behavior shows that it can be associated with the molecule of adsorbent [27]. Thus, characteristics and concentration gradient of the breakthrough curves vary significantly with respect to the bed height of the adsorbent, flow rate, and inlet dye concentration.

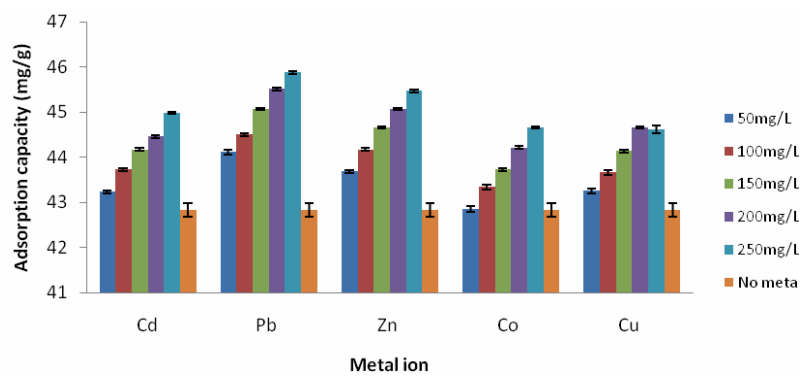

Fig. 9. Effect of the presence of heavy metal ions on adsorption potential of $\mathrm{MnFe}_{2} \mathrm{O}_{4}$ /clay composite for removal of Golden XGL dye.

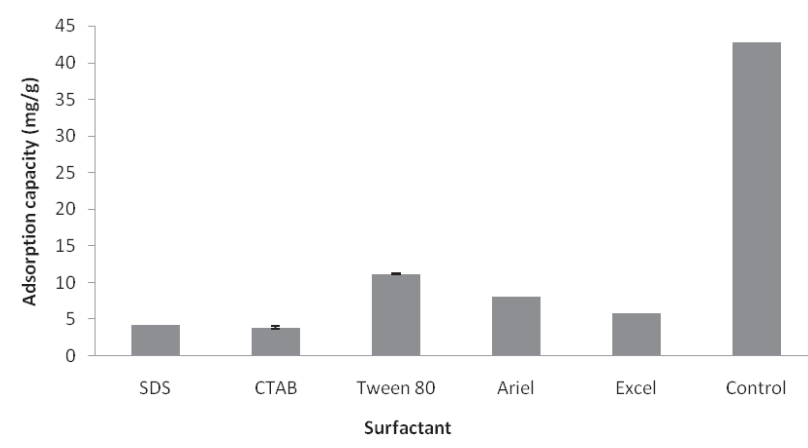

Fig. 10. Effect of the presence of surfactants/detergents on the adsorption potential of $\mathrm{MnFe}_{2} \mathrm{O}_{4}$ /clay composite for removal of Golden XGL dye.

The adsorption breakthrough curves were obtained at different bed heights $(1 \mathrm{~cm}$ to $3 \mathrm{~cm})$ while keeping initial dye concentration and flow rate constant, i.e., $50 \mathrm{mg} / \mathrm{L}$ and $1.8 \mathrm{~mL} / \mathrm{min}$, respectively. The results revealed that elevation in bed height results in more dye removal. In this case, breakthrough times increased with elevation of bed height as more binding sites became available for adsorption [28]. The increase in the mass of adsorbent also resulted in a broadened adsorption zone, and therefore a wider mass transfer zone. So the steepness of the breakthrough curves depends on bed height, which is due to the fact that the bed lengths tested are not high enough to ensure a fully developed profile, the so-called constant pattern behavior [27]. Adsorption columns were performed at different flow rates. Column breakthrough time was reduced from 390 to 130 minutes for Golden XGL with a rise in flow rate from 1.8-3.6 $\mathrm{mL} / \mathrm{min}$. This might be attributed to the reduction in retention time that limited contact of dye solution onto the clay composite. Inlet dye concentration varied from 50 to $100 \mathrm{mg} \mathrm{L}^{-1}$, which shifts the breakthrough curve yielding lower breakthrough times. The earlier appearance of the breakthrough time with increasing inlet dye concentration is due to a faster saturation of the available binding sites [29]. The results of flow rate optimization, bed height, and initial dye concentration while using continuous mode study are given in Table 6.

\section{Breakthrough Curves Modeling}

Experimental data was treated with a Thomas model and BDST model following equations (14) and (15), respectively:

$$
\ln \left(\frac{C_{o}}{C_{t}}-1\right)=\frac{K_{T h} \times q_{o} \times W}{Q}-K_{T h} \times C_{o} \times t
$$

...where $\mathrm{q}_{\mathrm{o}}(\mathrm{mg} / \mathrm{g})$ stands for equilibrium dye uptake per $\mathrm{g}$ of adsorbent, $\mathrm{k}_{\mathrm{Th}}(\mathrm{mL} / \mathrm{min} \mathrm{mg})$ denotes Thomas rate constant, $\mathrm{Q}(\mathrm{mL} / \mathrm{min})$ shows flow rate, $\mathrm{C}_{\mathrm{o}}(\mathrm{mg} / \mathrm{L})$ 
Table 6. Column data and parameters with different bed heights, flow rate, and inlet concentration for the removal of Golden XGL dye.

\begin{tabular}{|c|c|c|c|c|c|}
\hline $\begin{array}{c}\text { Inlet concentration } \\
(\mathrm{mg} / \mathrm{L})\end{array}$ & $\begin{array}{c}\text { Bed height } \\
(\mathrm{cm})\end{array}$ & $\begin{array}{c}\text { Flow rate } \\
(\mathrm{mL} / \mathrm{min})\end{array}$ & $\begin{array}{c}\text { Treated volume } \\
(\mathrm{mL})\end{array}$ & $\begin{array}{c}\text { Breakthrough point } \\
(50 \%) \\
(\mathrm{min})\end{array}$ & $\begin{array}{c}\text { Adsorption } \\
\text { capacity } \\
(\mathrm{mg} / \mathrm{g})\end{array}$ \\
\hline 50 & 1 & 1.8 & 234 & 130 & 10.81 \\
\hline 50 & 2 & 1.8 & 486 & 270 & 11.32 \\
\hline 50 & 3 & 1.8 & 702 & 390 & 12.23 \\
\hline 50 & 3 & 2.7 & 567 & 210 & 8.45 \\
\hline 50 & 3 & 3.6 & 468 & 130 & 6.75 \\
\hline 75 & 3 & 1.8 & 378 & 210 & 13.3 \\
\hline 100 & 3 & 1.8 & 198 & 130 & 15.8 \\
\hline
\end{tabular}

shows inlet dye concentration, $\mathrm{C}_{\mathrm{t}}(\mathrm{mg} / \mathrm{L})$ is outlet concentration at time $\mathrm{t}, \mathrm{t}_{\text {total }}(\mathrm{min})$ stands for flow time, and $\mathrm{W}(\mathrm{g})$ represents mass of adsorbent. A linear graph of $\ln$ $\left[\left(\mathrm{C}_{\mathrm{o}} / \mathrm{C}_{\mathrm{t}}\right)-1\right]$ against time $(\mathrm{t})$ was drawn to determine values of $\mathrm{k}_{\mathrm{Th}}$ and $\mathrm{q}_{\mathrm{o}}$ using intercept and slope of the plot:

$$
t=\frac{N o Z}{\operatorname{CoU}}-\frac{1}{K_{a} C_{o}} \ln \left(\frac{C_{o}}{C_{b}}-1\right)
$$

...where $\mathrm{C}_{\mathrm{o}}$ denotes the initial concentration of dye $(\mathrm{mg} / \mathrm{L}), \mathrm{C}_{\mathrm{b}}$ represents breakthrough dye concentration $(\mathrm{mg} / \mathrm{L}), \mathrm{k}_{\mathrm{a}}$ stands for rate constant in BDST model $(\mathrm{L} / \mathrm{mg} /$ $\min$ ), $\mathrm{U}$ shows linear velocity $(\mathrm{cm} / \mathrm{min}), \mathrm{N}_{\mathrm{o}}$ is adsorption capacity of the bed $(\mathrm{mg} / \mathrm{L}), \mathrm{Z}$ stands for bed height $(\mathrm{cm})$ of the column, and $t$ is time (min). Eq. (15) may be written in linear form as:

$$
t=a Z-b
$$

...where:

$$
a=\text { slope }=\frac{\mathrm{No}}{\mathrm{CoU}}
$$

...and:

$$
b=\text { intercept }=\frac{1}{K_{a} C_{o}} \ln \left(\frac{C_{o}}{C_{b}}-1\right)
$$

The results of the Thomas and BDST models are reported in Tables 7-8, and it displays that at different $\mathrm{C}_{\mathrm{t}} / \mathrm{C}_{\mathrm{o}}$ ratios, and correlation coefficient is higher in the case of BDST, which demonstrates good agreement of experimental data with the BDST model.

\section{FT-IR Study}

FT-IR spectra of the native clay and $\mathrm{MnFe}_{2} \mathrm{O}_{4}$ /clay composite (composite of highest adsorption capacity) before and after adsorption of the Golden XGL dye was studied in the range $400-4,000 \mathrm{~cm}^{-1}$ (Figs 14-16). The peak at 1,382.96 $\mathrm{cm}^{-1}$ was observed due to $\mathrm{CH}_{2}$ bending. The peak observed at $2,353.16 \mathrm{~cm}^{-1}$ is due to the presence of an $\mathrm{N}-\mathrm{H}$ bond while around $3,730.33 \mathrm{~cm}^{-1}$ shows the $\mathrm{O}-\mathrm{H}$ stretching vibrations. The peak in the region of 1,537.27 $\mathrm{cm}^{-1}$ reveals the presence of a benzene ring. The peak of around $850 \mathrm{~cm}^{-1}$ is observed due to $\mathrm{C}-\mathrm{H}$ stretching vibration. Quartz shows the characteristic peak at $781.17 \mathrm{~cm}^{-1}$ The peak around $900 \mathrm{~cm}^{-1}$ is due to the Si-O-Si linkages.

\section{Desorption Study}

The effect of different eluents on dye desorption was observed by using different chemical agents. The dye elution using $0.05 \mathrm{~N} \mathrm{HCl}$ was optimum, i.e., $33.8 \%$

Table 7. Thomas Model parameters for the removal of Golden XGL dye.

\begin{tabular}{|c|c|c|c|c|c|}
\hline $\begin{array}{c}\text { Inlet } \\
\text { conc. } \\
(\mathrm{mg} / \mathrm{L})\end{array}$ & $\begin{array}{c}\text { Bed } \\
\text { height } \\
(\mathrm{cm})\end{array}$ & $\begin{array}{c}\text { Flow } \\
\text { rate } \\
(\mathrm{mL} / \mathrm{min})\end{array}$ & $\begin{array}{c}\mathrm{K}_{\mathrm{Th}} \\
(\mathrm{mL} / \mathrm{min} \mathrm{mg}) \\
\times 10^{3}\end{array}$ & $\begin{array}{c}\mathrm{q}_{\mathrm{o}} \\
(\mathrm{mg} / \mathrm{g})\end{array}$ & $\mathrm{R}^{2}$ \\
\hline 50 & 1 & 1.8 & 0.38 & 10.98 & 0.983 \\
\hline 50 & 2 & 1.8 & 0.28 & 11.77 & 0.929 \\
\hline 50 & 3 & 1.8 & 0.18 & 12.46 & 0.971 \\
\hline 50 & 3 & 2.7 & 0.30 & 8.69 & 0.975 \\
\hline 50 & 3 & 3.6 & 0.38 & 6.94 & 0.984 \\
\hline 75 & 3 & 1.8 & 0.17 & 13.04 & 0.973 \\
\hline 100 & 3 & 1.8 & 0.15 & 15.58 & 0.946 \\
\hline
\end{tabular}

Table 8. BDST parameters for the removal of Golden XGL dye.

\begin{tabular}{|c|c|c|c|c|c|}
\hline $\mathrm{C}_{\mathrm{t}} / \mathrm{C}_{\mathrm{o}}$ & $\mathrm{A}$ & $\mathrm{B}$ & $\begin{array}{c}\mathrm{K}_{\mathrm{a}} \\
\left(\mathrm{Lmg}^{-1} \mathrm{~min}^{-1}\right)\end{array}$ & $\begin{array}{c}\text { No } \\
\left(\mathrm{mg} \mathrm{L}^{-1}\right)\end{array}$ & $\mathrm{R}^{2}$ \\
\hline 0.2 & 90 & 43.33 & 0.0006 & 1650 & 0.995 \\
\hline 0.4 & 110 & 3.333 & 0.0024 & 2017 & 0.997 \\
\hline 0.6 & 150 & 3.345 & 0.0025 & 2751 & 0.998 \\
\hline
\end{tabular}




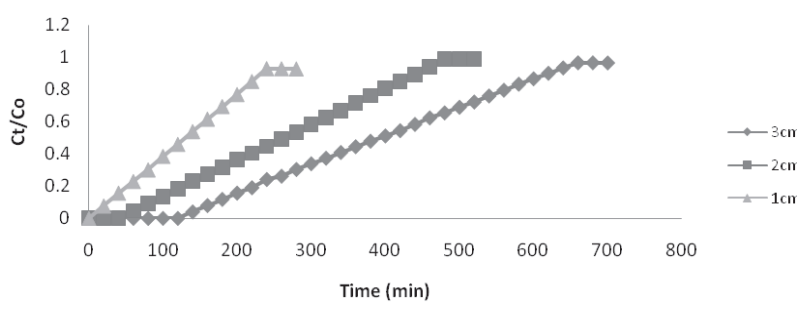

Fig. 11. Effect of bed height on removal of Golden XGL dye.

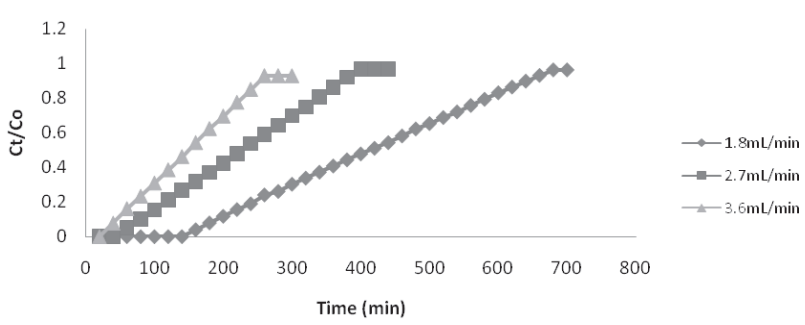

Fig. 12. Effect of flow rate on removal of Golden XGL dye.

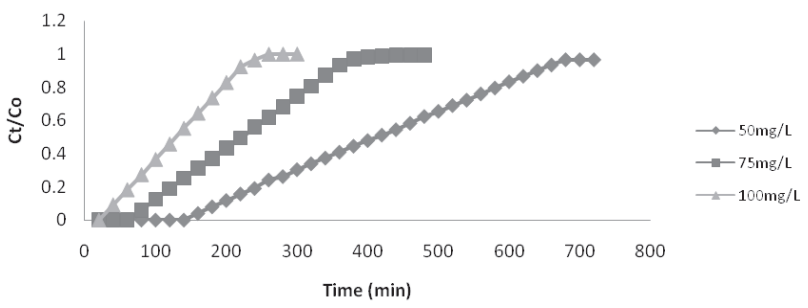

Fig. 13. Effect of initial dye concentration on removal of Golden XGL dye.

followed by $\mathrm{H}_{2} \mathrm{SO}_{4}(0.05 \mathrm{~N}), \mathrm{H}_{3} \mathrm{PO}_{4}(0.05 \mathrm{~N})$, ETOH $(0.05 \mathrm{~N}), \mathrm{NaCl}(0.05 \mathrm{~N})$, and $\mathrm{NaOH}(0.05 \mathrm{~N})$. The elution efficacy was further investigated at varying $\mathrm{HCl}$ concentrations. Maximum dye elution was achieved with $0.1 \mathrm{~N} \mathrm{HCl}$ solution, i.e., $57.4 \%$. When $\mathrm{HCl}$ concentration was further enhanced, less desorption was observed. This was attributed to the destruction of the adsorption sites onto the adsorbent surface at higher $\mathrm{HCl}$ concentrations (Table 9).

Table 9. FTIR spectra peaks of native clay, $\mathrm{MnFe}_{2} \mathrm{O}_{4}$ /clay composite, and Golden XGL dye loaded composite.

\begin{tabular}{|c|c|c|}
\hline $\begin{array}{c}\text { Native clay peak } \\
\left(\mathrm{cm}^{-1}\right)\end{array}$ & $\begin{array}{c}\mathrm{MnFe}_{2} \mathrm{O}_{4} \text { /clay } \\
\text { composite peak } \\
\left(\mathrm{cm}^{-1}\right)\end{array}$ & $\begin{array}{c}\text { Golden XGL dye } \\
\text { loaded composite } \\
\text { peak }\left(\mathrm{cm}^{-1}\right)\end{array}$ \\
\hline $3,730.33$ & $3,732.26$ & $3,730.33$ \\
\hline $2,551.82$ & $3,127.51$ & $2,667.55$ \\
\hline $2,351.23$ & $2,353.16$ & $1,838.16$ \\
\hline 993.31 & $1,382.96$ & $1,715.58$ \\
\hline 781.17 & 989.18 & $1,537.27$ \\
\hline 696.30 & 779.21 & 850.61 \\
\hline
\end{tabular}

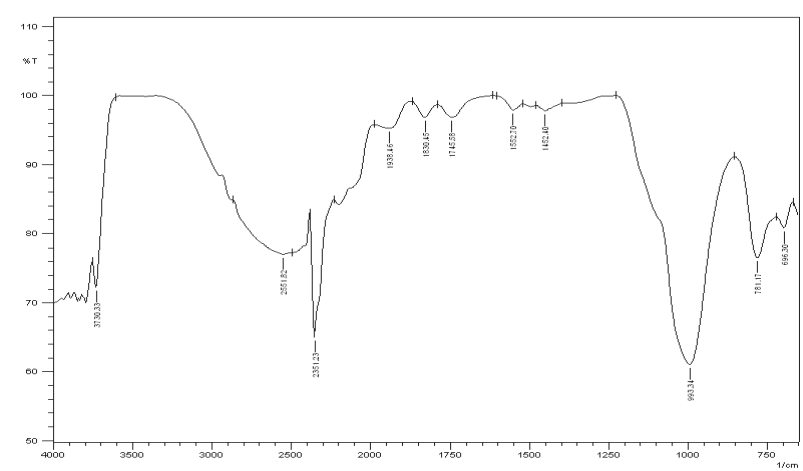

Fig. 14. FT-IR spectrum of native clay.

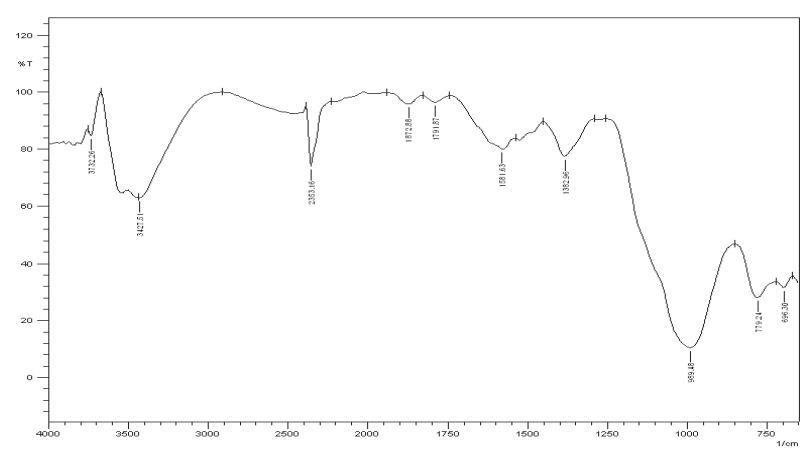

Fig. 15. FT-IR spectrum of $\mathrm{MnFe}_{2} \mathrm{O}_{4} /$ clay composite.

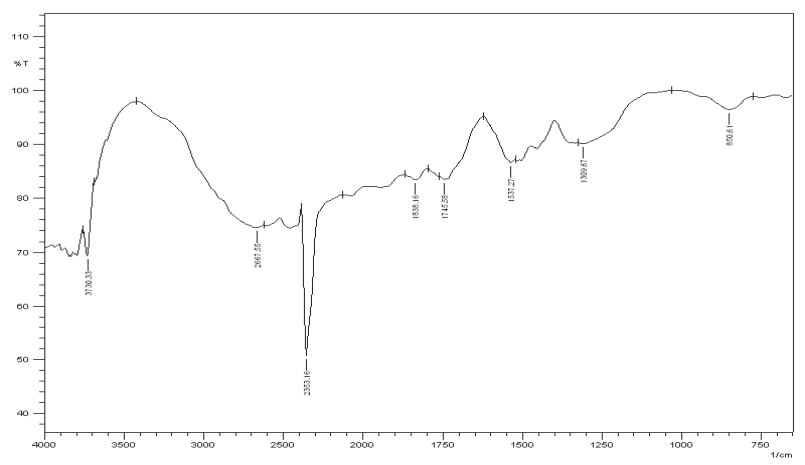

Fig. 16. FT-IR Spectrum of Golden XGL dye-loaded $\mathrm{MnFe}_{2} \mathrm{O}_{4} /$ clay composite.

\section{Conclusions}

Removal of Golden XGL dye by native clay and clay composites in batch mode and fixed-bed column was studied. The batch experimental results showed that alkaline $\mathrm{pH}$, low adsorbent dose, contact time of 3050 minutes, and low temperature were most favorable conditions for dye removal. We concluded that the DubininRadushkevich model fit successfully to the experimental data obtained by native clay, while the Langmuir model fit well to the data obtained by clay composites. A pseudo second-order kinetic model was fit appropriately to the kinetic data. Breakthrough time and breakthrough curves 
were strongly influenced by operational conditions, such as bed height, flow rate, and initial dye concentration. Experimental data fit well to the BDST model. Desorption could be successfully carried out using $\mathrm{HCl}$ as eluent.

\section{Acknowledgements}

This work is part of the Ph.D. thesis of Sana Nausheen. The authors are thankful to the Higher Education Commission (HEC) of Pakistan for financial assistance under the Indigenous Ph.D. Fellowship Program.

\section{References}

1. FARIA P.C.C., ORFAO J.J.M., PEREIRA M.F.R. Adsorption of anionic and cationic dyes on activated carbons with different surface chemistries. Water Res, 38 (8), 2043, 2004.

2. BAJPAI S.K., NAVIN C., MANIKA M. The adsorptive removal of cationic dye from aqueous solution using poly (methacrylic acid) Hydrogels:Part-I. equlibrium studies. Int. J. Environ. Sci, 2, 1609, 2012.

3. SHAWABKEH R.A., TUTUNJI M.F. Experimental study and modeling of basic dye sorption by diatomaceous clay. Appl. Clay Sci, 24, 111, 2003.

4. WU R., QU J. Removal of water-soluble azo dye by the magnetic material $\mathrm{MnFe}_{2} \mathrm{O}_{4}$. J. Chem. Technol. Biotechnol, 27, 20, 2005.

5. AI L., ZHOU Y., JIANG J. Removal of methylene blue from aqueous solution by montmorillonite/ $\mathrm{CoFe}_{2} \mathrm{O}_{4}$ composite with magnetic separation performance. Desalination, 266, 72, 2011

6. HASHEMIAN S. $\mathrm{MnFe}_{2} \mathrm{O}_{4}$ /bentonite nano composite as a novel magnetic material for adsorption of acid red 138. Afr. J. Biotechnol, 9, 8667, 2010.

7. GONG J.L., WANG B., ZENG G.M., YANG C.P., NIU C.G., NIU Q.Y., ZHOU W.J., LIANG Y.Removal of cationic dyes from aqueous solution using magnetic multi-wall carbon nanotube nanocomposite as adsorbent. J. Hazard. Mater, 164, 1517, 2009.

8. REDDY D.H.K., LEE S.M. Application of magnetic chitosan composites for the removal of toxic metal and dyes from aqueous solutions. Adv. Colloid Interface Sci, 201, 68, 2013.

9. ALMEIDA C.A.P., DEBACHER N.A., DOWNSC A.J., COTTETA L., MELLO C.A.D. Removal of methylene blue from colored effluents by adsorption on montmorillonite clay. J. Colloid Interface Sci, 332, 46, 2009.

10. SARI A., TUZEN M., CITAK D., SOYLAK M. Equilibrium, kinetic and thermodynamic studies of adsorption of $\mathrm{Pb}(\mathrm{II})$ from aqueous solution onto Turkish kaolinite clay. J. Hazard. Mater, 149, 283, 2007.

11. SEKAR M., SAKTHI V., RENGARAJ S. Kinetics and equilibrium adsorption study of lead(II) on activated carbon prepared from coconut shell. J. Colloid Interface Sci, 279, 307, 2004.

12. FENG Q., LIN Q., GONG F., SUGITA S., SHOYA M. Adsorption of lead and mercury by rice husk ash. J. Colloid Interface Sci, 278, 1, 2004.

13. NOREEN S., BHATTI H. N., NAUSHEEN S., SADAF S., ASHFAQ M. Batch and fixed bed adsorption study for the removal of DrimarineBlack CL-B dye from aqueous solution using a lignocellulosic waste:A cost affective adsorbent. Indust. Crops Prod, 50, 568, 2013.
14. ASGHER M., BHATTI H.N. Removal of reactive blue 19 and reactive blue 49 textile dyes by citrus waste biomass from aqueous solution: equilibrium and kinetic study. Can. J. Chem. Eng, 9999,1, 2011.

15. REPO E., WARCHOL J.K., KURNIAWAN T.A., SILLANPAA M.E.T. Adsorption of $\mathrm{Co}(\mathrm{II})$ and $\mathrm{Ni}(\mathrm{II})$ by EDTA- and/or DTPA-modified chitosan: kinetic and equilibrium Modeling. Chem. Eng. J, 161, 73, 2010.

16. PAN H., SHEN Q., XU J., LUO M. Surface mercapto engineered magnetic $\mathrm{Fe}_{3} \mathrm{O}_{4}$ nanoadsorbent for the removal of mercury from aqueous solutions. J. Colloid Interf. Sci, 365, 204, 2012.

17. SADAF S., BHATTI H.N., NAUSHEEN S., NOREEN S. Potential Use of Low-Cost Lignocellulosic Waste for the Removal of Direct Violet 51 from Aqueous Solution: Equilibrium and Breakthrough Studies. Arch. Environ. Contam. Toxicol, 66, 557, 2014.

18. TUNC O., TANACI H., AKSU Z. Potential use of cotton plant wastes for theremoval of Remazol Black B reactive dye. J. Hazard. Mater, 163, 187, 2009.

19. ASGHER M., BHATTI H.N. Mechanistic and kinetic evaluation of biosorption of reactive azo dyes by free, immobilised and chemically treated Citrus sinensis waste. Ecol. Eng, 36, 1660, 2010.

20. FENG Y., YANG F., WANG Y., MA L., WU Y., KERR P.G., YANG L. Basic dye adsorp-tion onto an agro-based waste material-Sesame hull (Sesamum indicum L.). Bioresour. Technol, 102, 10280, 2011.

21. PENG Q., LIU Y., ZENG G., XU W., YANG C., ZHANG J. Biosorption of copper(II) by immobilizing Saccharomyces cerevisiae on the surface of chitosan-coated magnetic nanoparticles from aqueous solution. J. Hazard. Mater, 177, 676, 2010.

22. HALL K.R., EAGLETON L.C., ACRIVOS A., VERMEULEN T. Pore and solid diffusion kinetics in fixed bed adsorption under constant pattern conditions. Ind. Eng. Chem. Fundam, 5, 212, 1966.

23. SADAF S., BHATTI H.N. Equilibrium modeling for adsorptive removal of Indosol Black NF dye by low-cost agro-industrial waste: batch and continuous study. Desalin. Water Treat, 52, 4492, 2014.

24. KAREEM S.H., HUSSIEN E.A. Adsorption of Congo, Red Rhodamine B and Disperse blue dyes from aqueous solution onto raw flint clay. J. Baghdad Sci, 9, 680, 2012.

25. HAQ I., BHATTI H.N., ASGHER M. Removal of solar red BA textile dye from aqueous solution by low cost barley husk: Equilibrium, kinetic and thermodynamic study. Can J Chem Eng, 89, 593, 2011.

26. BHATTI H.N., NAUSHEEN S. Equilibrium and kinetic modeling for the removal of Turquoise Blue PG dye from aqueoussolution by a low cost agro-waste. Desalin. Water Treat, 55, 1934, 2015.

27. SOTELO J.L., RODRIGUEZ A., ALVAREZ S., GARCIA J. Removal of caffeine and diclofenac on activated carbon in fixed bed column, Chem. Eng. Res. Des, 90, 967, 2012.

28. VIJAYARAGHAVAN K., YUN Y.S. Polysulfoneimmobilized Corynebacterium glutamicum: A biosorbent for Reactive Black 5 from aqueous solution in an up-flow packed column. Chem. Eng. J, 145, 44, 2008.

29. LEZEHARI M., BAUDU M., BOURAS O., BASLY J. P. Fixed-bed column studies of pentachlorophenol removal by use of alginate-encapsulated pillared clay microbeads. J. Colloid Interf. Sci, 379, 101, 2012. 